\title{
CONGENITAL MALFORMATIONS AND ENVIRONMENTAL INFLUENCES IN PREGNANCY
}

\author{
BY \\ I. D. GERALD RICHARDS, M.D. (Wales), D.P.H. ${ }^{1}$ \\ Department of Social and Occupational Medicine, Welsh National School of Medicine, Cardiff
}

Most human congenital malformations are believed to be due to the interaction of both genetic and environmental influences. Neither retrospective enquiry (e.g., Record, 1958) nor prospective study (e.g., McDonald, 1961) has yet been of much value in uncovering the environmental factors responsible and, with the exception of maternal rubella infection and a small number of drugs (notably thalidomide), the nature of these influences is still not known.

In the South Wales Survey of Congenital Defects, a register has been compiled of defects occurring among all births in 1964-66 to women resident in

TABLE I

THE CASES INVESTIGATED

\begin{tabular}{|c|c|c|}
\hline System & Defect & No. \\
\hline \multirow[t]{2}{*}{ Central nervous } & $\begin{array}{l}\text { Anencephaly } \\
\text { Spina bifida cystica } \\
\text { Other }\end{array}$ & $\begin{array}{r}107 \\
140 \\
32\end{array}$ \\
\hline & Total & 279 \\
\hline \multirow[t]{2}{*}{ Cardiovascular } & $\begin{array}{l}\text { Septal defect } \\
\text { Patent ductus arteriosus } \\
\text { Aortic defect } \\
\text { Other }\end{array}$ & $\begin{array}{l}21 \\
16 \\
29 \\
34\end{array}$ \\
\hline & Total & 100 \\
\hline \multirow[t]{2}{*}{ Alimentary } & $\begin{array}{l}\text { Cleft lip/palate } \\
\text { Pyloric stenosis } \\
\text { Other }\end{array}$ & $\begin{array}{l}66 \\
39 \\
68\end{array}$ \\
\hline & Total & 173 \\
\hline \multirow[t]{2}{*}{ Musculo-skeletal } & $\begin{array}{l}\text { Reduction deformity } \\
\text { Dislocation of hip } \\
\text { Talipes } \\
\text { Other }\end{array}$ & $\begin{array}{l}11 \\
15 \\
92 \\
34\end{array}$ \\
\hline & Total & 152 \\
\hline \multirow[t]{2}{*}{ Miscellaneous } & $\begin{array}{l}\text { Mongolism } \\
\text { Eye, ear } \\
\text { Urogenital } \\
\text { Skin } \\
\text { Other }\end{array}$ & $\begin{array}{l}32 \\
16 \\
15 \\
46 \\
20\end{array}$ \\
\hline & Total & 129 \\
\hline All systems & & 833 \\
\hline
\end{tabular}

1 Present address: Social Paediatric Research Group, 23 Montrose Street, Glasgow, C.1.
South Wales, viz., the county boroughs of Cardiff, Swansea, Merthyr Tydfil, and Newport, and the administrative counties of Glamorgan and Monmouthshire. As part of the epidemiological investigation of these defects, and in an attempt to identify possible aetiological factors, a retrospective study was made of 833 consecutive cases (Table I) and an equal number of matched controls-being women who had given birth to normal (i.e., non-malformed) infants, matched for maternal age, parity, social class, area of residence, and date of delivery $( \pm 2$ weeks).

The interviews were conducted in the homes bx health visitors and local authority assistant medicat officers and usually took place in the second mont after delivery. Each member of a pair (the case and its control) were questioned by the same interviewer. Because of the nature of the enquiry, interviews could not be conducted 'blind'; this being so, as much information as possible concerning the congenital defect was given to the interviewer.

The factors investigated were in four groups (Table II) and related to two periods: (a) the first trimester, defined as the first 16 weeks of pregnancy, and $(b)$ subsequent trimesters. Whenever possible, the date of the end of the first trimester was given to the interviewer.

TABLE II

THE FACTORS INVESTIGATED

Group A: Illnesses in the First Trimester and Concurrent Illnesses

\begin{tabular}{|c|c|}
\hline Factors Investigated & Particulars Recorded \\
\hline $\begin{array}{l}\text { Nausea } \\
\text { Vomiting } \\
\text { Fainting }\end{array}$ & $\begin{array}{l}\text { Severity (mild, moderate, severe) } \\
\text { Severity (mild, moderate, severe) } \\
\text { Number of episodes and stage(s) of preg- }\end{array}$ \\
\hline Bleeding & $\begin{array}{l}\text { Stage of pregnancy and whether at time of } \\
\text { an expected period }\end{array}$ \\
\hline $\begin{array}{l}\text { Accidents } \\
\text { Coughs and colds } \\
\text { Other febrile illnesses } \\
\text { Concurrent illnesses }\end{array}$ & $\begin{array}{l}\text { Stage of pregnancy and nature } \\
\text { Stage of pregnancy } \\
\text { Stage of pregnancy and nature } \\
\text { Stage of pregnancy (for diabetes mellitus, } \\
\text { cardiac disease, asthma, tuberculosis, } \\
\text { migraine, mental illness, others) }\end{array}$ \\
\hline
\end{tabular}

For all illnesses, the type and duration of treatment were recorded.

(cont.) 
TABLE II (cont.)

Group B: Drugs, etc.

\begin{tabular}{|c|c|}
\hline Factors Investigated & Particulars Recorded \\
\hline Drugs (oral therapy) & $\begin{array}{l}\text { Stage of pregnancy, nature of drug, reason } \\
\text { and duration of use (for antibiotic, } \\
\text { sulphonamide, steroid, salicylate, seda- } \\
\text { tive, iron preparation, others) }\end{array}$ \\
\hline Contraceptive & Use of oral and/or chemical contraceptive \\
\hline $\begin{array}{l}\text { General anaesthetic } \\
\text { X-ray }\end{array}$ & $\begin{array}{l}\text { Stage of pregnancy and reason } \\
\text { Stage of pregnancy and part X-rayed }\end{array}$ \\
\hline Smoking & $\begin{array}{l}\text { Number smoked per day, whether regularly } \\
\text { and whether she gave up for part of } \\
\text { pregnancy }\end{array}$ \\
\hline Diet & $\begin{array}{l}\text { A subjective impression by the interviewer } \\
\text { of the adequacy of the diet during the } \\
\text { first trimester recorded as 'not } \\
\text { balanced', 'doubtful' or 'normal'; details } \\
\text { were recorded. }\end{array}$ \\
\hline
\end{tabular}

Group C: Employment, Accommodation, Water Supply, Height, and Weight in the First Trimester

\begin{tabular}{|c|c|}
\hline Factors Investigated & Particulars Recorded \\
\hline Employment & Nature, duration and whether sedentary \\
\hline $\begin{array}{l}\text { Accommodation } \\
\text { Bedroom density } \\
\text { Water supply } \\
\text { Height } \\
\text { Weight }\end{array}$ & $\begin{array}{l}\text { Type (own, shared or other, e.g., caravan) } \\
\text { Ratio bedrooms used : number of occupants } \\
\text { Type of supply (tap, well, other) } \\
\text { Mother's statement } \\
\text { Mother's statement of weight before preg- } \\
\text { nancy or during first trimester" }\end{array}$ \\
\hline
\end{tabular}

- Confirmed, whenever possible, from the mother's 'pregnancy continuity card' (this fact recorded)

Group D: Miscellaneous Factors, Some having Genetic Implications

\begin{tabular}{l|l}
\hline Factors Investigated & \multicolumn{1}{|c}{ Particulars Recorded } \\
\hline $\begin{array}{l}\text { Area of parents' birth } \\
\text { Blood group }\end{array}$ & $\begin{array}{l}\text { County of birth } \\
\text { Mother's ABO and Rhesus group from } \\
\text { Blood Transfusion Service report, con- } \\
\text { tinuity card or obstetric record } \\
\text { First cousin marriage of child's parents } \\
\text { Age at time of child's birth } \\
\text { Duration at time of child's birth } \\
\text { In child's siblings and parents: nature of } \\
\text { Paternal age } \\
\begin{array}{c}\text { Duration of marriage } \\
\text { Family history of recorded } \\
\text { congenital defect }\end{array}\end{array}$ \\
\hline
\end{tabular}

For the cases and controls resident in Cardiff, hospital and local authority obstetric notes were examined, and general practitioners were invited to give particulars of illnesses in pregnancy and of treatments prescribed.

The frequency of each of the factors investigated was calculated for cases and controls-by diagnosis, by system affected, and for all defects combined. The chi-square test was then applied to determine the levels of statistical significance of the differences found.

\section{RESULTS}

A statistically significant excess among cases was found for many of the factors investigated. Those relating to the first trimester are shown in the Figure.

\section{Group A}

For all systems combined, there were significant differences for bleeding $(P<0.05)$, accidents $(P<0.01)$, coughs and colds $(P<0.05)$, and other febrile illnesses $(P<0.01)$.

The following significant differences were present for individual systems:

Central nervous system: accidents $(P<0.01)$

Cardiovascular system: nausea $(P<0.05)$

Alimentary tract: vomiting, bleeding, coughs and colds, other febrile illnesses (all $P<0.05)$.

Within the various systems, significant differences (all $P<0.05$ ) were present for the following defects:

Anencephaly:

accidents

Septal defects: febrile illnesses

Cleft lip and/or palate: nausea and vomiting

Other alimentary: nausea

Talipes:

Skin defects: other illnesses

bleeding and other illnesses

The rates for accidents in the first and subsequent trimesters are shown in Table III. Significant first trimester differences have been listed above; there were none in subsequent trimesters. Although accidents of all types and degrees of severity were included, the majority of those reported were falls.

TABLE III ACCIDENTS IN PREGNANCY (Rates for controls are shown in parentheses)

\begin{tabular}{|c|c|c|c|c|}
\hline \multirow[b]{2}{*}{ Defect } & \multicolumn{2}{|c|}{ 1st Trimester } & \multicolumn{2}{|c|}{$\begin{array}{l}\text { 2nd and 3rd } \\
\text { Trimesters }\end{array}$} \\
\hline & $\begin{array}{c}\text { Accident } \\
(\%)\end{array}$ & $\begin{array}{l}\text { Signi- } \\
\text { ficance } \\
\text { Level }\end{array}$ & $\begin{array}{c}\text { Accident } \\
(\%)\end{array}$ & $\begin{array}{l}\text { Signi- } \\
\text { ficance } \\
\text { Level }\end{array}$ \\
\hline $\begin{array}{l}\text { Central nervous } \\
\text { Cardio-vascular } \\
\text { Alimentary } \\
\text { Musculo-skeletal } \\
\text { Miscellaneous }\end{array}$ & $\begin{array}{rr}12.9 & (5 \cdot 0) \\
9 \cdot 0 & (10 \cdot 0) \\
11.6 & (5 \cdot 8) \\
7 \cdot 2 & (5 \cdot 3) \\
4 \cdot 7 & (4 \cdot 7)\end{array}$ & $1 \%$ & $\begin{array}{l}21 \cdot 1(20.4) \\
17.0(19 \cdot 0) \\
27.2(20.2) \\
18.4(21.0) \\
14.7(22.5)\end{array}$ & \\
\hline All defects & $9 \cdot 8 \quad(5 \cdot 8)$ & $1 \%$ & $20.4(20.6)$ & \\
\hline Anencephaly & $17 \cdot 8 \quad(7 \cdot 5)$ & $5 \%$ & $15 \cdot 0(16 \cdot 8)$ & \\
\hline
\end{tabular}

\section{Group B}

For all systems combined, there were significant differences for salicylates $(P<0.001)$, sedatives $(P<0.05)$, other drugs $(P<0.001)$, and dietary imbalance $(P<0.05$.

The percentages of all cases and controls having each type of drug are shown in Table IV. An important feature of the table is the absence of 
GROUP FACTORS INVESTIGATED

A

\section{Nausea \\ Vomiting}

Fainting

Bleeding

Accidents

Coughs and colds

Other febrile illnesses

Concurrent and other illnesses

B

Antibiotic

Sulphonamide

Steroid

Salicylate

Sedative

Iron

Other drugs

Contraceptive (oral or chemical)

General anaesthetic

$X$-ray

Smoking

Diet

C

D

Employment

Accommodation : type

Water supply

Height

Weight

Area of parents' birth

Blood group

Cousin marriage

Paternal age

Duration of marriage

Family history of congenital defect-sibling -father -mother bedroom density
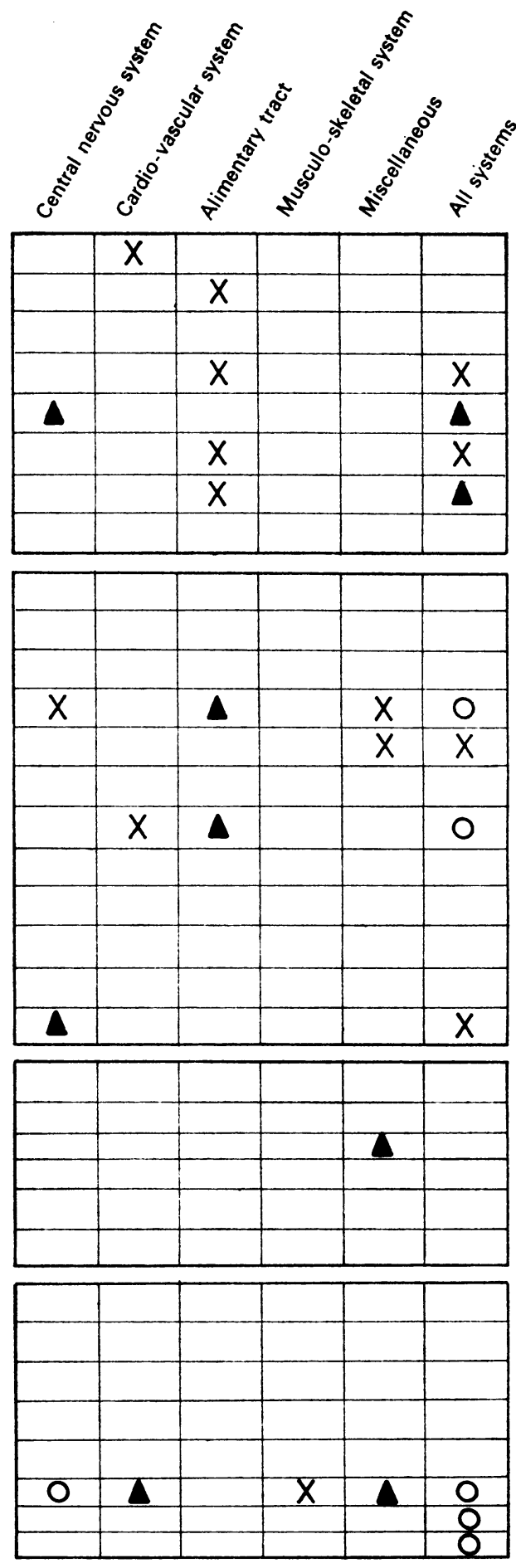
TABLE IV

DRUGS IN PREGNANCY

(Rates for controls are shown in parentheses)

\begin{tabular}{|c|c|c|c|c|}
\hline \multirow[b]{2}{*}{ Drug } & \multicolumn{2}{|c|}{ 1st Trimester } & \multicolumn{2}{|c|}{$\begin{array}{l}\text { 2nd and 3rd } \\
\text { Trimesters }\end{array}$} \\
\hline & $\begin{array}{c}\text { Took Drug } \\
(\%)\end{array}$ & $\begin{array}{c}\text { Signi- } \\
\text { ficance } \\
\text { Level }\end{array}$ & $\begin{array}{c}\text { Took Drug } \\
(\%)\end{array}$ & $\begin{array}{l}\text { Signi- } \\
\text { ficance } \\
\text { Level }\end{array}$ \\
\hline $\begin{array}{l}\text { Antibiotic } \\
\text { Sulphonamide } \\
\text { Steroid } \\
\text { Salicylate } \\
\text { Sedative } \\
\text { Iron } \\
\text { Others }\end{array}$ & $\begin{array}{r}5.5(4.6) \\
0.5(0.7) \\
0.7(0.2) \\
22.3(14.4) \\
8.4(5.3) \\
43.1(43.0) \\
37.9(28.9)\end{array}$ & $\begin{array}{l}0.1 \% \\
5 \% \\
0.1 \%\end{array}$ & $\begin{array}{r}8.3(8 \cdot 2) \\
1.8 \quad(1.0) \\
0.6(0.4) \\
28.5(24 \cdot 2) \\
15.0(15 \cdot 2) \\
79.8(80.6) \\
47.1(43.8)\end{array}$ & \\
\hline
\end{tabular}

significant differences for drugs taken in the second and third trimesters.

The following significant differences were present for individual systems:

Cental nervous system:

salicylates $(P<0.05)$ dietary imbalance

$(\mathbf{P}<0.01)$

Cardiovascular

system:

other drugs $(\mathrm{P}<0.05)$

Alimentary tract:

salicylates $(\mathrm{P}<0.01)$

other drugs $(\mathrm{P}<0.01)$

Miscellaneous defects: salicylates $(P<0.05)$

sedatives $(\mathrm{P}<0.05)$

Within the various systems, the following significant differences were present:

Anencephaly:

dietary imbalance

$$
(P<0.01)
$$

Spina bifida cystica: dietary imbalance

$$
(P<0.05)
$$

Aortic defects: $\quad$ other drugs $(P<0.05)$

Cleft lip and/or palate: other drugs $(P<0.001)$

Other alimentary defects:

Talipes:

Eye and ear defects:

and car defects:

Mongolism:

other drugs $(P<0.05)$ dietary imbalance $(P<0.05)$ salicylates $(P<0.01)$ other drugs $(P<0.05)$ sedatives $(P<0.05)$

Tables $\mathrm{V}$ and VI show the rates for salicylates taken and for the group of miscellaneous drugs. These tables show those defects for which there were marked differences between the rates for cases and controls, but in some instances not sufficiently great to reach levels of statistical significance. One notable feature of these tables is the absence (with one exception) of significant differences for drugs taken in the second and third trimesters.

Among the group of miscellaneous drugs taken
TABLE V

SALICYLATES IN PREGNANCY

\begin{tabular}{|c|c|c|c|c|}
\hline \multirow[b]{2}{*}{ Defect } & \multicolumn{2}{|c|}{ 1st Trimester } & \multicolumn{2}{|c|}{$\begin{array}{l}\text { 2nd and 3rd } \\
\text { Trimesters }\end{array}$} \\
\hline & $\begin{array}{c}\text { Took Drug } \\
(\%)\end{array}$ & $\begin{array}{l}\text { Signi- } \\
\text { ficance } \\
\text { Level }\end{array}$ & $\begin{array}{c}\text { Took Drug } \\
(\%)\end{array}$ & $\begin{array}{l}\text { Signi- } \\
\text { ficance } \\
\text { Level }\end{array}$ \\
\hline $\begin{array}{l}\text { Central nervous } \\
\text { Cardio-vascular } \\
\text { Alimentary } \\
\text { Musculo-skeletal } \\
\text { Miscellaneous } \\
\text { All }\end{array}$ & $\begin{array}{l}24 \cdot 0(16 \cdot 5) \\
13.0(15 \cdot 0) \\
25 \cdot 4(13.3) \\
22.4(13.8) \\
21 \cdot 7(11.6) \\
22.3(14 \cdot 4)\end{array}$ & $\begin{array}{l}5 \% \\
1 \% \\
5 \% \\
0.1 \%\end{array}$ & $\begin{array}{l}31 \cdot 9(25 \cdot 8) \\
22 \cdot 0(28 \cdot 0) \\
27 \cdot 7(25 \cdot 4) \\
24 \cdot 3(23 \cdot 7) \\
31 \cdot 8(17 \cdot 1) \\
28 \cdot 5(24 \cdot 2)\end{array}$ & $1 \%$ \\
\hline $\begin{array}{l}\text { Anencephaly } \\
\text { Spina bifida } \\
\text { Cleft lip/palate } \\
\text { Pyloric stenosis } \\
\text { Other alimentary } \\
\text { Talipes }\end{array}$ & $\begin{array}{l}24 \cdot 0(16 \cdot 5) \\
25 \cdot 0(17 \cdot 1) \\
27 \cdot 3(12 \cdot 1) \\
20 \cdot 5(10 \cdot 3) \\
26 \cdot 5(16 \cdot 2) \\
26 \cdot 1(14 \cdot 1)\end{array}$ & $1 \%$ & $\begin{array}{l}28.0(26.2) \\
35.7(25.0) \\
31.8(27.3) \\
20.5(23.1) \\
27.9(25.0) \\
23.9(21.7)\end{array}$ & \\
\hline
\end{tabular}

(Rates for controls are shown in parentheses)

TABLE VI

MISCELLANEOUS DRUGS IN PREGNANCY

\begin{tabular}{|c|c|c|c|c|}
\hline \multirow[b]{2}{*}{ Defect } & \multicolumn{2}{|c|}{ 1st Trimester } & \multicolumn{2}{|c|}{$\begin{array}{l}\text { 2nd and 3rd } \\
\text { Trimesters }\end{array}$} \\
\hline & $\begin{array}{c}\text { Took Drug } \\
(\%)\end{array}$ & $\begin{array}{l}\text { Signi- } \\
\text { ficance } \\
\text { Level }\end{array}$ & Took Drug & $\begin{array}{l}\text { Signi- } \\
\text { ficance } \\
\text { Level }\end{array}$ \\
\hline $\begin{array}{l}\text { Central nervous } \\
\text { Cardio-vascular } \\
\text { Alimentary } \\
\text { Musculo-skeletal } \\
\text { Miscellaneous } \\
\text { All }\end{array}$ & $\begin{array}{l}38.4(32.6) \\
36.0(20.0) \\
45.7(31.2) \\
30.9(25.0) \\
36.4(29.5) \\
37.9(28.9)\end{array}$ & $\begin{array}{l}5 \% \\
1 \% \\
0.1 \%\end{array}$ & $\begin{array}{l}45 \cdot 2(42 \cdot 3) \\
45 \cdot 0(42 \cdot 0) \\
50 \cdot 3(46 \cdot 8) \\
50 \cdot 7(42 \cdot 1) \\
44 \cdot 2(46 \cdot 5) \\
47 \cdot 1(43.8)\end{array}$ & \\
\hline $\begin{array}{l}\text { Septal defect } \\
\text { Patent ductus } \\
\text { Aortic defect } \\
\text { Other C.V.S. } \\
\text { Cleft lip/palate } \\
\text { Pyloric stenosis } \\
\text { Other alimentary } \\
\text { Eye, ear }\end{array}$ & $\begin{array}{l}57 \cdot 1(14 \cdot 3) \\
18 \cdot 8(31 \cdot 3) \\
37.9(20.7) \\
29 \cdot 4(17 \cdot 6) \\
56 \cdot 1(24 \cdot 2) \\
33 \cdot 3(53 \cdot 8) \\
42.6(25.0) \\
62.5(12.5)\end{array}$ & $\begin{array}{l}5 \% \\
0.1 \% \\
5 \% \\
5 \%\end{array}$ & $\begin{array}{l}66 \cdot 7(38 \cdot 1) \\
25 \cdot 0(43 \cdot 8) \\
41.4(55 \cdot 2) \\
44.1(32.4) \\
47.0(47.0) \\
59.0(66.7) \\
48.5(35.3) \\
50.0(50.0)\end{array}$ & \\
\hline
\end{tabular}

(Rates for controls are shown in parentheses)

by mothers giving birth to babies with cleft lip and/or palate are the anti-emetics. Vomiting in early pregnancy was reported by 27 of the 66 cases studied and by 11 of the controls; 17 of the cases took antiemetics but only 10 of the controls (Table VII).

TABLE VII

HISTORY OF VOMITING AND USE OF ANTI-EMETICS IN FIRST TRIMESTER

\begin{tabular}{l|c|c}
\hline & $\begin{array}{c}\text { Cases (cleft lip } \\
\text { and/or palate) }\end{array}$ & Controls \\
\cline { 2 - 3 } & 10 & 1 \\
Vomiting: no anti-emetics & 17 & 10 \\
No vomiting & 39 & 55 \\
& 66 & 66 \\
\hline
\end{tabular}

Table VIII shows the rates for dietary standards in the first trimester for each system and for those 
TABLE VIII

DIET DURING FIRST TRIMESTER

(Rates for controls are shown in parentheses)

\begin{tabular}{|c|c|c|c|c|}
\hline Defect & $\begin{array}{c}\text { Not } \\
\text { 'Balanced' }\end{array}$ & Doubtful & Normal & $\begin{array}{l}\text { Signifi- } \\
\text { cance } \\
\text { Level }\end{array}$ \\
\hline $\begin{array}{l}\text { Central nervous } \\
\text { Cardio-vascular } \\
\text { Alimentary } \\
\text { Musculo-skeletal } \\
\text { Other }\end{array}$ & $\begin{array}{l}3.2(3.9) \\
6.0(6.0) \\
4.6(2.9) \\
7.2(6.6) \\
4.7(3.1)\end{array}$ & $\begin{array}{r}17.6(7.9) \\
13.0(8.0) \\
8.1(6.9) \\
9.2(10.5) \\
11.6(11.6)\end{array}$ & $\begin{array}{l}78.5(88.2) \\
82.0(85.0) \\
86.7(90.2) \\
83.6(82.9) \\
83.7(85.3)\end{array}$ & $1 \%$ \\
\hline All systems & $4 \cdot 8(4 \cdot 3)$ & $12.6(8 \cdot 8)$ & $82.4(87.0)$ & $5 \%$ \\
\hline \multirow{2}{*}{$\begin{array}{l}\text { Anencephaly } \\
\text { Spina bifida } \\
\text { Alimentary } \\
\text { (other) }\end{array}$} & $\begin{array}{l}4.7(5.6) \\
1.4(2.9)\end{array}$ & $\begin{array}{ll}26 \cdot 2 & (9 \cdot 3) \\
13.6 & (5 \cdot 0)\end{array}$ & $\begin{array}{l}68 \cdot 2(85 \cdot 0) \\
84 \cdot 3(92 \cdot 1)\end{array}$ & $5 \%$ \\
\hline & $8.8(1.5)$ & $10.3 \quad(4 \cdot 4)$ & $79.4(94 \cdot 1)$ & $5 \%$ \\
\hline
\end{tabular}

defects showing significant differences. Differences were small for those said to have diets which were 'not balanced'-with the exception of other alimentary defects. There were, however, marked differences in diets considered 'doubtful' for most systems and for the individual defects listed.

\section{GrouP C}

The bedroom density (ratio of bedrooms: occupants) differed significantly for miscellaneous defects $(P<0.01)$, there being more cases than controls with high ratios.

For individual defects there were significant differences for the following:

Anencephaly: maternal weight-heavier than controls $(P<0.05)$

Talipes: bedroom density-more cases with low ratios $(P<0.05)$

\section{Group D}

There were no significant differences for the parents' area of birth, maternal blood group, paternal age or duration of marriage.

For all systems combined, there was a highly significant $(P<0.001)$ difference for a family history of congenital defect-both for siblings and for each parent. In siblings also, this significant excess was present for most systems, viz., central nervous (P $<0.001)$, cardiovascular $(P<0.01)$, musculoskeletal $(P<0.05)$, and for miscellaneous defects (P <0.01).

These differences were due almost entirely to a recurrence of the same or similar (i.e., same system) defect. Among individual defects there were significant differences for spina bifida and for the group of other central nervous system defects (both $P<0.05)$.

\section{Discussion}

The limitations of a retrospective enquiry of this kind are several and cannot be overlooked.

(1) The results may be affected by bias on the part of the interviewer or the mother, whose statements may be coloured by the knowledge that her infant is either normal or abnormal.

(2) Events may be forgotten, the nature of the drugs and dosage not known, and the timing of events inaccurate.

(3) In this study the whole of the first trimester has been considered, whereas the critical periods of development are short and occur at different times for different organs.

(4) Another difficulty in this investigation is that a large number of tests of significance were performed and many of these apparently significant differences could have arisen merely by chance (Table IX).

TABLE IX

TESTS OF STATISTICAL SIGNIFICANCE

\begin{tabular}{c|c|ccc}
\hline & \multirow{3}{*}{$\begin{array}{c}\text { Tests } \\
\text { Performed }\end{array}$} & \multicolumn{3}{|c}{ Values of P }
\end{tabular}

The numbers that could have occurred merely by chance are shown in parentheses

Nevertheless, where the obstetric notes of patients have been scrutinized and general practitioner reports submitted, the author has been impressed by the accuracy of the mothers' statements. Had bias on the part of the mothers or interviewers played an important role in producing statistically significant differences for events in the first trimester, it might be expected that such differences would occur in the later trimesters also. The striking lack of such differences suggests that those found for first trimester events are real.

Interobserver differences and the possibility that positive findings are the result of observer bias are $\tilde{\nabla}$ lessened by using many observers. This enquiry was conducted by 58 interviewers and this fact lends weight to the likelihood that the positive findings are real.

Among the positive findings recorded above, those 0 of particular interest are the results for salicylate administration, for the group of miscellaneous ? drugs (including anti-emetics), and for diet. 


\section{Salicylate Preparations}

The results of this investigation suggest that either salicylates have a teratogenic effect or that the conditions for which they are given have such an action. This finding is of particular interest in view of the frequency with which women of childbearing age take aspirin. Carter (1964) has estimated that perhaps as many as a half take at least one tablet containing aspirin in early pregnancy.

Salicylates produce congenital malformations in mice and rats, probably by inhibiting the synthesis of acid mucopolysaccharide (Larsson, Boström, and Ericson, 1963). Among the defects produced in rats are craniorachischisis, exencephaly, and hydrocephaly (Warkany and Takacs, 1959).

Carter and Wilson (1963) have reported an increased pregnancy wastage rate following the administration of salicylates in a small series in general practice but due entirely to abortions. In the pilot analysis of the Outcome of Pregnancy Survey conducted by the Royal College of General Practitioners, based on 1,038 pregnancies, there was no evidence of a teratogenic effect from salicylatecontaining preparations (Slater, 1965). But it was shown that in order to achieve a total of 100 patients taking aspirin at some time during the first eight weeks following conception, it would be necessary to investigate about 2,500 pregnancies, and the results of the full survey of at least 10,000 cases should provide valuable evidence on this matter.

In our investigation, there was a wide range in the dosage of salicylate taken, and it is particularly interesting that, on such a crude measure of drug intake, several statistically significant differences should have been found between cases and controls. These results demand an ad hoc enquiry into the possible teratogenic effect of salicylates.

\section{Miscellaneous Drugs}

Prominent among this group of drugs were antiemetics, the nature of many being unknown. One of these drugs, meclozine, has received much attention, and several studies have suggested that it has no teratogenic effect in the human (e.g., Carter and Wilson, 1962; Smithells and Chinn, 1964). But Lenz (1966) has shown that, if data from 15 studies are pooled, among 3,333 infants whose mothers were given meclozine in the first trimester, 12 had a cleft lip and/or palate. This number is two to three times that expected.

The results of the investigation reported here do not permit a definite conclusion to be reached on the possible teratogenic effect of anti-emetic drugs. It is possible, of course, that vomiting in early pregnancy or a hormonal imbalance associated with pregnancy sickness may have a teratogenic effect. The ratio of cases to controls when no anti-emetics were taken for vomiting in the first trimester $(10: 1)$ is much greater than when antiemetics were taken $(17: 10)$, and this is evidence against a teratogenic action by anti-emetic drugs in the aetiology of cleft lip and/or palate.

\section{DIET}

Congenital malformations have been produced in experimental animals by a wide variety of deficiencies in the maternal diet. The literature on this subject was reviewed by Kalter and Warkany (1959) and among the dietary deficiencies shown to have teratogenic effects are those of vitamin A, thiamine, riboflavine, niacin, pantothenic acid, vitamin $E$, and folic acid. Hypervitaminosis $A$ is also teratogenic in experimental animals, and Millen and Woollam (1958) have shown that the incidence of cleft palate in rats induced by hypervitaminosis $A$ is much lower if the vitamins of the B group are administered at the same time. The degree of dietary deficiency needed to induce malformations in experimental animals need not be great. For example, Giroud (1960) found that a riboflavine level in the mother's liver only 20 to 30 below normal was teratogenic.

Coffey and Jessop (1958) have suggested that dietary deficiency may be an aetiological factor in anencephaly. They found evidence of a higher prevalence of defective nutrition among the mothers of anencephalics than among a control group. There was also a marked excess of unemployed fathers among the cases and they showed that in the lower income groups in Dublin the average intakes of calcium, vitamin A, riboflavine, and vitamin $\mathbf{C}$ were below the recommended allowance.

Burke, Beal, Kirkwood, and Stuart (1943) found that in a group of mothers, whose diet in pregnancy was classified as 'poor' or 'very poor', there was a significantly higher $(P<0.01)$ malformation rate than among those having a 'good' or 'excellent' diet.

In a blind controlled retrospective study of pregnancy diets, Pitt and Samson (1961) demonstrated the following dietary deficiencies: cleft lip and/or palate-thiamine ( $\mathrm{P}<0.05)$; congenital heart defects-protein, iron, vitamin $C(P<0.05)$, carbohydrate, and niacin $(P<0.01)$; talipes-riboflavine, niacin, vitamin $C(P<0.05)$; mongolism and spina bifida cystica-none; all malformed infants-carbohydrate, iron, thiamine, vitamin C $(P<0.05)$, and niacin $(P<0.01)$.

It has been shown that folate deficiency may 
produce malformations, including central nervous system defects and cleft lip and palate, in the rat embryo (Evans, Nelson, and Asling, 1951; Nelson 1960). Studies in Liverpool suggest that there is a relationship between malformations of the fetus and defective folate metabolism based on FIGLU tests performed late in pregnancy or in the early puerperium (Hibbard and Smithells, 1965).

It is interesting, therefore, that for central nervous system defects there was a significant excess (among the cases) of diets judged to be unbalanced or doubtful. This was also true of two separate defects-anencephaly and spina bifida cystica. Although these differences could be accounted for by bias on the part of the observers, this seems unlikely as they were present in each of the six local authority areas in the investigation.

The results of this study do not permit any conclusion to be made concerning the nature of the dietary deficiencies suspected of having aetiological importance in the central nervous system malformations. In none of the defects investigated was there a significantly lower weight (pre-pregnancy or in the first trimester) among the cases, suggesting that, if dietary deficiencies play a part in the causation of congenital defects, they are not of such a nature as to produce underweight. (In fact, the mothers of anencephalics were significantly heavier than matched controls).

\section{OTHER FACTORS}

Defects of the central nervous system show a marked social class distribution, having a higher incidence in the lower income groups than in the upper, and this is especially true of anencephalus (Edwards, 1958). It has been suggested that this may be due to an increased liability to infection through overcrowding. In this study, using controls matched for several factors including social class, the only significant differences detected in standards of accommodation, judged by bedroom density, were for talipes (higher density among cases) and for miscellaneous defects (lower density among cases).

Anderson, Baird, and Thomson (1958), in their analysis of 37,585 single births in Aberdeen, demonstrated an excess of central nervous system malformations in small women and they suggested that this association reflected standards of childhood nutrition. In the study reported here, there was no demonstrable relationship between congenital abnormality and maternal height.

In a prospective study of 3,295 pregnancies, McDonald (1961) found an increased malformation risk in three groups-following a febrile illness in the first trimester, in tuberculous patients, and in laundry workers. But in a study of chest clinic patients, Lowe (1964) was unable to confirm McDonald's findings of an excess of malformations in births to tuberculous patients. In the investigation reported here, the only defects in which a history of cough, cold or other febrile illness occurred significantly more often among the cases were septal defects and all alimentary tract defects combined.

\section{SUMmary}

As part of an epidemiological study of congenital malformations in South Wales, a retrospective enquiry was made of 833 pregnancies which resulted in the birth of malformed infants and of an equal number of matched controls. Many statistically significant differences were found between cases and controls, those of greatest interest (and possible importance) being:

(1) the taking of salicylate preparations in the first trimester (all systems, $P<0.001$ ); central nervous system, $P<0.05$; alimentary tract, $P<0.01$; miscellaneous defects, $P<0.05$; talipes, $P<0.01$ ); (2) the taking of drugs in a miscellaneous group including anti-emetics (all systems, $P<0.001$ cardiovascular system, $\mathrm{P}<0.05$; alimentary tract $P<0.01$; aortic defects, $P<0.05$; cleft lip and/oon palate, $P<0.001$; other alimentary defects; $P<0.05$; eye and ear defects, $P<0.05$ );

(3) a diet in the first trimester considered to be 'unbalanced' or 'doubtful' (all systems, $P<0.05$; central nervous system, $P<0.01$; anencephaly, $P<0.01$; spina bifida cystica, $P<0.05$; other alimentary defects, $P<0.05$ ).

Although the findings of this survey do not permit any definite conclusion to be reached regarding the nature of the environmental factors concerned in human teratogenesis, they do suggest several lines of further investigation.

I wish to acknowledge the valuable guidance and criticism received during the investigation from Professor C. R. Lowe. My thanks are due also to Dr. Hubert Campbell for statistical advice, to Miss Kathleen Davies and Miss Margaret Phipps for selecting controls, to the Medical Officers of Health of Cardiff, Swansea, Newport, Merthyr Tydfil, Glamorgan, and Monmouthshire for their interest and co-operation, and to the Divisional Medical Officers and administrative staffs for their help. Much of the day-to-day administration of the survey was undertaken by Mrs. Mair Broome, who also conducted the interviews in Cardiff and Newport; to her and to the assistant medical officers and health visitors who interviewed in the other areas 
especial thanks are due for their diligence and interest. I am grateful also to the general practitioners who submitted details of drugs and illnesses in pregnancy, to Miss Patricia Johnstone and Mrs. Elizabeth Walker who assisted with the statistical analysis, and to Dr. M. P. Carter for advice and the loan of his M.D. thesis. British Olivetti Limited kindly lent a 'Programma 101 electronic desk-top computer', and the research was supported by a grant from the Association for the Aid of Crippled Children, New York.

\section{REFERENCES}

Anderson, W. J. R., Baird, D., and Thomson, A. M. (1958). Epidemiology of stillbirths and infant deaths due to congenital malformation. Lancet, 1, 1304.

Burke, Bertha S., Beal, Virginia A., Kirkwood, S. B., and StuART, H. C. (1943). Nutritional studies during pregnancy. Amer. J. Obstet. Gynec., 46, 38.

CARTER, M. P. (1964). Relationship between antibiotic therapy in early pregnancy and congenital malformations. M.D. thesis, University of Oxford.

- and WrLson, F. W. (1962). "Ancoloxin" and foetal abnormalities. Brit. med. J., 2, 1609.

- - (1963). Antibiotics and congenital malformations. Lancet, 1, 1267.

Coffey, Victoria P., and Jessop, W. J. E. (1958). A three years study of anencephaly in Dublin: a report on 181 cases. Irish J. med. Sci., No. 393, p. 391.

EDWARDS, J. H. (1958). Congenital malformations of the central nervous system in Scotland. Brit. J. prev. soc. Med., 12, 115.

Evans, H. M., Nelson, Marjorie M., and Asling, C. W. (1951). Multiple congenital abnormalities resulting from acute folic acid deficiency during gestation. Science, $114,479$.

GIROUD, A. (1960). In Ciba Foundation Symposium on Congenital Malformations. Ed. Wolstenholme, G. E. W., and O'Connor, Cecilia M., p. 129. Churchill, London.
HibBard, E. D., and Smithells, R. W. (1965). Folic acid metabolism and human embryopathy. Lancet, 1, 1254.

Kalter, H., and Warkany, J. (1959). Experimental production of congenital malformations in mammals by metabolic procedure. Physiol. Rev., 39, 69.

Larsson, K. S., Boström, H., and Ericson, Birgitta (1963). Salicylate-induced malformations in mouse embryos. Acta Paediat. (Uppsala), 52, 36.

LENZ, W. (1966). Malformations caused by drugs in pregnancy. Amer. J. Dis. Child, 112,99.

Lows, C. R. (1964). Congenital defects among children born to women under supervision or treatment for pulmonary tuberculosis. Brit.J. prev. soc. Med., 18, 14.

McDonald, Aluson D. (1961). Maternal health in early pregnancy and congenital defect. Ibid., 15, 154 .

Millen, J. W., and Woollam, D. H. M. (1958). Effect of vitamin B complex on the teratogenic effects of hypervitaminosis A. Nature (Lond.), 182, 940.

Nelson, Marjorie M. (1960). In A Ciba Foundation Symposium on Congenital Malformations. Ed. Wolstenholme, G. E. W., and O'Connor, Cecilia M, p. 134. Churchill, London.

PrtT, D. B., and Samson, Patricia E. (1961). Congenital malformations and maternal diet. Aust. Ann. Med., 10, 268.

RECORD, R. G. (1958). Environmental influences in the aetiology of congenital malformations. Proc. roy. Soc. Med., 51, 147.

Slater, B. C. S. (1965). The investigation of drug embryopathies in man. In Symposium on Embryopathic Activity of Drugs. Ed. Robson, J. M., Sullivan, F. M., and Smith, R. L., p. 241. Churchill London.

Smithells, R. W., and ChinN, Elizabeth R. (1964). Meclozine and foetal malformations: a prospective study. Brit. med. J., 1, 217.

WARRANY, J., and TAKacs, Eva (1959). Experimental production of congenital malformations in rats by salicylate poisoning. Amer. J. Path., 35, 315. 